Original Research Paper

\title{
Islamic Finance Development and Economic Growth Nexus: The Case of the United Arab Emirates (UAE)
}

\author{
${ }^{1}$ Abdelghani Echchabi and ${ }^{2}$ Dhekra Azouzi \\ ${ }^{1}$ College of Business, Effat University, Jeddah 22332, Saudi Arabia \\ ${ }^{2}$ Faculty of Management and Economic Sciences, El-Manar University, El-Manar 1, Tunisia
}

Article history

Received: 28-5-2015

Revised: $16-7-2015$

Accepted: 3-8-2015

Corresponding Author:

Abdelghani Echchabi

College of Business, Effat

University, Jeddah 22332,

Saudi Arabia

Email: abdelghani.mo@gmail.com

\begin{abstract}
Islamic Banking presently knows a great success and new Islamic banks are opening every day all over the world. This Shari'ah (It is the bod of Islamic law, it literally means "way" or "path") compliant banking is expected to withstand the financial crises and to enhance economic growth. In this paper, the purpose is to analyse the relationship between Islamic banking development and economic growth in the UAE from Q1: 2004 to Q4: 2011 using co-integration and Granger causality tests. This study reveals that no relationship does exist between Islamic banking development and economic growth in the UAE. Such a result can be attributed to the small component of Islamic banking in the global banking sector and to its declining profitability in the period of study. The study enriches the literature on Islamic finance development and economic growth, which is still an under-researched area, especially in the MENA region.
\end{abstract}

Keywords: Islamic Banking, Islamic Finance, Economic Growth, UAE

\section{Introduction}

The study of financial development-economic growth nexus emerged in the early 19th century. The subsequent financial economic theoreticians e.g., McKinnon (1973) and Shaw (1973) demonstrated that the restriction of financial systems through various measures impedes financial development which is essential to the economic growth. Similarly, the theory highlights the significance of the economic growth to the financial development notably through the impact of financial services on capital accumulation and technological innovation (Abu-Bader and Abdu-Qarn, 2006).

Subsequently, a growing body of literature has covered this topic in several contexts and using various estimations for both financial development and economic growth (Sunde, 2012; Stievano, 2004; Halicioglu, 2007; Abu-Bader and Abu-Qarn, 2006; AlMalkawi and Abdullah, 2011; Pradhan, 2009; Conley, 2012; Stolbov, 2013; Khan, 2000; Shan and Jianhong, 2006; Ujunwa et al., 2012; Al-Malkawi et al., 2012). Generally there are at least three types of causal relationships found between financial development and economic growth, namely, supply-leading, demandfollowing and bi-directional causal relationships. It is noteworthy that the proponents of the supply leading hypothesis suggest that financial development precedes economic growth, while the opposite is argued by the demand following proponents. These studies were recently extended to the Islamic finance-economic growth nexus with the emergence and development of modern Islamic finance.

Islamic finance emerged as an alternative to the existing conventional finance. In line with the Islamic principles and teachings, Islamic finance prohibits riba (The word "Riba", in Arabic language, literally means an "increment' or addition". In Islamic law the term riba has a special meaning. Riba is an unjustified increment in borrowing or lending money, paid in kind or in money above the amount of loan, as a condition imposed by the lender. Riba also is an unjustified increment gained by the seller or the buyer if they exchanged goods of the same kind in different quantities (Ahmad, nd, 2009), gharar (Gharar means doubtfulness or uncertainty as in the case of not knowing whether an event will occur or otherwise, excluding the unknown (Al-Saati, 2003)) and gambling, as well as other practices that violate the principles of justice and equitable distribution that are fundamental values in Islam. It is worth noting that Islamic finance has witnessed tremendous growth in the last few decades and has been introduced in many countries, not only in the Muslim world, but also in other non-Muslim countries. 
Hence, Islamic financing could be an alternative for macroeconomic development in these countries.

Currently, the studies on Islamic financing and economic growth nexus are still scarce. One of the early studies was by Furqani and Mulyani (2009) who have examined the Islamic finance and economic growth nexus in the case of Malaysia. The authors used quarterly data from 1997 through 2005 and have applied co-integration and Vector Error Correction Models (VECM). Their findings indicated that in both the long run and short run, there is evidence of bi-directional relationship between Islamic financing and fixed investment.

In the same context, Abdul Manap et al. (2012) have also examined the relationship between Islamic banking development and economic growth in Malaysia using Toda-Yamamoto and Bootstrap granger non causality tests. The study covered the period of 1998 through 2012 in quarterly form. The findings provide evidence of unidirectional relationship from Islamic financial development towards economic growth.

In a more recent study, Abduh and Omar (2012) have investigated the short- and long run relationships between development of Islamic banking and the economic growth in Indonesia, using quarterly data spanning from 2003 through 2010. By using Autoregressive Distributed Lag (ARDL) model, the authors found an evidence of a bi-directional relationship between both the variables.

Similarly, Abduh and Chowdhury (2012) explored the relationship between Islamic finance development and economic growth in the case of Bangladesh. The authors used quarterly data spanning from 2004 through 2011 and applied co-integration and Granger causality tests. Their findings indicated that in both short and long run, there is a unidirectional relationship running from Islamic financing to economic growth.

In a different context, Goaied and Sassi (2011) studied the relationship between Islamic financing and economic growth in selected Middle East and North African (MENA) countries. The authors used unbalanced panel data set and applied system GMM estimation for dynamic panel model. Their findings indicated that there is no significant relationship between Islamic financing and economic growth in the selected markets. Nevertheless, the main weakness of this study is that the countries selected are of different economic and financial development and the spread between these two might not be consistent across MENA countries. Thus, the output of the study might be biased.

It is worth noting that the studies on Islamic finance development and economic growth nexus are still scarce, as shown in the above studies. Furthermore, none of the studies thus far has focused on the fast growing country of UAE. It goes without saying that this kind of studies is very relevant to emerging countries and particularly countries that have witnessed tremendous growth in either or both economy and financial markets, which can subsequently be used as a tool for further growth and development of the country as a whole (Azouzi and Echchabi, 2013).

Hence, the current study is an attempt to fill up this gap. Specifically, the objective of the current study is to examine the relationship between the Islamic finance development and economic growth in the case of United Arab Emirates (UAE). The study uses three proxies to achieve this objective, namely, total trade, Gross Fixed Capital Formation (GFCF) and GDP growth. Accordingly, the following research questions are to be addressed by this study:

- Is there a relationship between Islamic financing and GDP growth in UAE?

- Is there a relationship between Islamic financing and GFCF in UAE?

- Is there a relationship between Islamic financing and trade activities in UAE?

The remainder of the paper is organised as follows: The next section will deal with the financial and economic system of the UAE; Section 3 will discuss the methodology applied and the data used in the study, while the last two sections discuss the findings of the study and their implications, as well as the limitations of the study and the recommendations for future studies.

\section{UAE Financial and Economic System}

The United Arab Emirates (UAE) is an Arab country located in the South East of the Arabian Peninsula on the Arabian Gulf. UAE is a federation of seven states, namely, Abu Dhabi, Ajman, Dubai, Fujairah, Ras Al-Khaimah, Sharjah and Umm Al-Quwain, each of them is governed by an Emir. The population of the country is estimated at 7.9 million as of 2011. The country is also rich in natural resources, mainly, Petroleum and natural gas.

The country has witnessed continuous economic growth for the last few years. Its GDP has increased from USD270 billion in 2009 to USD300 billion in 2010 and USD360 billion in 2011. Similarly, the economic openness of the country has been reflected by the increasing foreign direct investments flowing to the country which has reached USD8 billion in 2011 compared to USD5.5 billion in 2010 and USD4 billion in 2009. On the other hand, the exports of the country have increased from USD192 billion in 2009 to USD212 billion in 2010 and USD253 billion in 2011 (Based on World Bank data). Overall, the macroeconomic environment in the country is considered as one of the highest worldwide as it is ranked $7^{\text {th }}$ globally (World Economic Forum statistics). 
Besides, the UAE financial system is considered as one of the most developed globally located at the 25 th position worldwide (World Economic Forum statistics). This shows that the UAE market in not only competitive regionally but globally as well. And this might have been due to the open economy system applied by the government authorities.

Though the contribution of Islamic finance to the whole financial system of the UAE is still negligible, which is roughly $16 \%$, in 2010 (Miniaoui and Gohou, 2011), it has witnessed a remarkable growth in the last few years amounting to approximately $15 \%$ annually (http://www.globalislamicfinancemagazine.com retrieved on 26th March 2013) and this rate is increased to $20 \%$ in 2011 (Rivzi, 2012). This indicates that the gap between conventional and Islamic finance contribution to the UAE financial market is narrowing, which shows that in the very near future, Islamic finance will have a major role to play in the development endeavour undertaken by the country.

\section{Methodology}

In order to depict the eventual relationship between Islamic banking and economic growth in UAE, the study uses quarterly time series data (2004:1 - 2011:4) for the following four variables: Islamic Bank total financing, real GDP, real Gross Fixed Capital Formation (GFCF) and Trade. The first one is employed as a proxy of the Islamic financial sector and the three others are representing the real economic sector (Furqani and Mulyani, 2009). These data are gathered from the BankScope World Bank and Bloomberg databases. These data are converted to log normal forms.

Looking for a best understanding of the nexus between the Islamic banking development and economic growth in UAE, the analysis begins by checking if the variables are stationary to detect after that if a cointegration relationship and/or a Granger-causality exists between the components of the variables' set.

It is worthy to mention that despite the numerous and recent unit root tests, the study relies on only two most commonly used tests, namely, the Augmented Dickey-Fuller (ADF) and Phillips-Perron tests suggested respectively by Dickey and Fuller (1979) and Phillips and Perron (1988).

Once the order of integration of the series is determined, the next step consists in checking if a cointegration relationship exists between the variables via the trace and maximal eigenvalue tests developed by Johansen and Juselius (1990). These two tests' results depend on the lag length that is why it should be chosen thoroughly in order to avoid the biased estimations. The presence of a co-integration relationship means that there is a long-run relationship between variables and its absence reveals that there is no common trend in the variables' dynamics. Finally, Granger causality
(Granger, 1969) is used to investigate the short run relationships between the selected variables.

\section{Empirical Results}

\section{Unit Root Tests}

For the unit root tests, the lags are determined automatically by Eviews 6 . The ADF and PP tests reveal that all the series are non-stationary at levels and that they should be differentiated. Hence, it appears clearly that our series are stationary at their first differences at $5 \%$ level of confidence; they are integrated of order 1 i.e., I (1), as it is shown in Table 1.

The next step is to apply the co-integration analysis to examine the long run relationship between the above mentioned variables. This is possible at this stage since the series are non-stationary at levels and stationary at first difference, which is a condition for $\mathrm{JJ}$ co-integration analysis.

\section{Co-Integration Tests}

First of all, it is noteworthy that the lag length selected for co-integration tests is of four quarters. This test aims at looking for long-run associations between Islamic finance and economic growth in UAE. The trace and maximal eigenvalue tests' results are gathered in Table 2.

Table 2 shows no evidence of co-integration between Islamic finance development and economic growth in UAE. Such finding comes in contradiction with Abduh and Chowdhry (2012) that focused on the contribution of Islamic banking to economic growth in Bangladesh in which the authors do depict a positive and significant relationship between Islamic bank financing and economic growth in the short and long run.

This result denying the presence of relationships between the set of variables designed to serve as proxies of economic growth and Islamic banking development is confirmed by Granger causality test shown in Table 3 . The table reveals that there is no short-run causality between Islamic banking total financing and real GDP, real Gross Fixed Capital Formation (GFCF) and trade as it was found by co-integration tests.

Such an ambiguous result can be explained by the fact that, despite the high number of financial institutions in UAE (Miniaoui and Gohou, 2011), Islamic financial institutions remain representing only $20 \%$ of the global banking sector in the UAE as of 2011 (Rivzi, 2012) which still relatively small. Moreover, this result can be attributed to the painful decline of around $10 \%$ in profitability experienced by the UAE during the period of study (The World Islamic Banking Competitiveness Report, 2011-2012). 
Abdelghani Echchabi and Dhekra Azouzi / American Journal of Economics and Business Administration 2015, 7 (3): 106.111 DOI: 10.3844/ajebasp.2015.106.111

Table 1. ADF and PP tests results

\begin{tabular}{|c|c|c|c|c|}
\hline \multirow[b]{2}{*}{ Variables } & \multicolumn{2}{|c|}{ ADF test $\mathrm{H}_{0}$ : Unit root } & \multicolumn{2}{|c|}{ PP test $\mathrm{H}_{0}$ : Unit root } \\
\hline & Level & First difference & Level & First difference \\
\hline \multicolumn{5}{|l|}{ GFCF } \\
\hline Test statistic & 2.01756 & -6.1150 & 3.99962 & -6.5709 \\
\hline $5 \%$ critical value & -1.95210 & -2.9640 & -1.95210 & -2.9640 \\
\hline \multicolumn{5}{|l|}{ GDP } \\
\hline Test statistic & 2.00398 & -6.0993 & 3.95914 & -6.4328 \\
\hline $5 \%$ critical value & -1.95210 & -2.9640 & -1.95210 & -2.9640 \\
\hline \multicolumn{5}{|l|}{ IBTF } \\
\hline Test statistic & -3.01410 & -1.1415 & -3.03880 & -10.3120 \\
\hline $5 \%$ critical value & -3.58750 & -1.9539 & -3.56290 & -2.9640 \\
\hline \multicolumn{5}{|l|}{ Trade } \\
\hline Test statistic & 1.98929 & -6.0906 & 3.48759 & -6.3761 \\
\hline $5 \%$ critical value & -1.95210 & -2.9640 & -1.95210 & -2.9640 \\
\hline
\end{tabular}

Table 2. Co-integration rank tests

\begin{tabular}{lllll}
\hline Rank & Eigenvalue & Trace test & p-value & $\lambda$ max test \\
\hline GFCF-IBTF & & & & p-value \\
0 & 0.207901 & $8.068133(15.49471)$ & 0.4582 & $6.292845(14.26460)$ \\
1 & 0.063636 & $1.775287(3.841466)$ & 0.1827 & $1.775287(3.841466)$ \\
GDP-IBTF & & & & \\
0 & 0.196844 & $7.332805(15.49471)$ & 0.5392 & $5.918558(14.26460)$ \\
1 & 0.051031 & $1.414247(3.841466)$ & 0.2344 & $1.414247(14.26460)$ \\
Trade-IBTF & & & & 0.6237 \\
0 & 0.192108 & $7.843808(15.49471)$ & 0.4822 & 5.2344 \\
1 & 0.074281 & $2.083985(3.841466)$ & 0.1488 & $2.083985(3.841466)$
\end{tabular}

Note: Figures in parentheses are the corresponding critical values at $5 \%$ confidence level

Table 3. Granger causality test

\begin{tabular}{lll}
\hline Null hypothesis & F-statistic & p-value \\
\hline IBTF does not Granger Cause GFCF & 0.07655 & 0.9265 \\
GFCF does not Granger Cause IBTF & 0.27398 & 0.7626 \\
IBTF does not Granger Cause GDP & 0.51288 & 0.6049 \\
GDP does not Granger Cause IBTF & 0.50892 & 0.6072 \\
IBTF does not Granger Cause Trade & 0.24065 & 0.7879 \\
Trade does not Granger Cause IBTF & 0.49589 \\
\hline
\end{tabular}

However, this is not the first study that ends with such conclusions and this finding comes to support the suggestion advanced by Goaied and Sassi (2011) who described the relationship between financial development and economic growth to be 'less general than it is mentioned by the theory and that it depends on the sample and the period chosen in the study Indeed, the Goaied and Sassi (2011) empirical study run for 16 countries in the MENA region revealed a nonsignificant relationship between Islamic banking and economic growth.

Hence, this result which can be described as somewhat "unexpected" supports, as it is mentioned by El-Galfy and Khiar (2012), 'the hypothesis that Islamic banking is a main channel of economic growth' has gained only a mixed support.

Nonetheless, It is worthy to note that this finding is in contradiction with the Furqani and Mulyani (2009) and Abdul Manap et al. (2012) where the authors found a great support to the Islamic banking and economic growth nexus in Malaysia and Abduh and Chowdhury (2012) whose conclusion is in favour of the important role of Islamic banking in enhancing economic growth in Bangladesh. It contradicts also the findings of Abduh and Omar (2012) who found a significant evidence of the relationship between Islamic banking development and economic growth respectively in Indonesia.

\section{Discussion}

The main objective of the study was to examine the relationship between Islamic finance development and the economic growth in UAE, represented by trade activities, GFCF and the GDP growth. The findings showed that there is no relationship between the two variables both in the long and short run.

This finding has significant contributions to the literature, regulators and policy makers as well as to the practitioners. Specifically, the study enriches the literature by extending the study on Islamic finance and 
economic growth nexus to a new context, namely UAE. Similarly, it uses relatively new data that reflects the recent economic growth and Islamic finance development in UAE and the remaining GCC countries.

The findings of the study provide insights to the policy makers and practitioners on the possible measures to implement in order to optimally use either or both Islamic finance development and economic growth for the overall development of the countries' economy. Since there is no relationship between Islamic finance development and economic growth in the case of UAE, the country's authorities should implement necessary measures to strategically develop both equally.

\section{Conclusion}

Though the current study has brought about significant contributions, it might still suffer from a number of limitations. Firstly, the study focused on one country only, which means that it cannot be generalized to the other countries of the region. Secondly, it has used data from 2004 to 2011 and this period witnessed a number of crises and bubbles, which were ignored in this study. Hence, future studies are recommended to include a larger number of countries in the region and consider the possible influence of the crises and bubbles that happened during the study period. Similarly, the future studies are recommended to use various control variables across countries such as the level of corruption, the culture, etc. Finally, the future studies are recommended to use more advanced statistical techniques for data analysis.

\section{Acknowledgment}

The authors would like to thank the anonmous reviewers as well as the associate editor for their efforts and valuable feedback.

\section{Author's Contributions}

Abdelghani Echchabi and Dhekra Azouzi: Problem formulation, literaure review and data analysis.

\section{Ethics}

This article is original and contains unpublished material. The corresponding author confirms that all of the other authors have read and approved the manuscript and no ethical issues involved.

\section{References}

Abduh, M. and M.A. Omar, 2012. Islamic banking and economic growth: The Indonesian experience. Int. J. Islamic Middle Eastern Finance Manage., 5: 35-47. DOI: $10.1108 / 17538391211216811$
Abduh, M. and N.T. Chowdhury, 2012. Does Islamic banking matter for economic growth in Bangladesh? J. Islamic Economics, Bank. Finance, 8: 104-113.

Abdul Manap, T.A., M. Abduh and M.A. Omar, 2012. Islamic banking-growth nexus: Evidence from todayamamoto and bootstrap granger causality test. J. Islamic Finance, 1: 59-66.

Abu-Bader, S. and A. Abu-Qarn, 2006. Financial developent and economic growth nexus: Time series evidence from middle eastern and north African countries. Discussion Paper No. 06-09, Monaster Center for Economic Research, Ben-Gurion University of the Negev, Beer Sheva, Israel.

Ahmad, A.Y. (nd), 2009. Riba, its economic rationale and implications. Institute of Islamic Banking and Insurance, London.

Al-Malkawi, H.N. and N. Abdullah, 2011. Financegrowth nexus: Evidence from a panel of MENA countries. Int. Res. J. Finance Economics, 63: 129-139.

Al-Malkawi, H.N., H.A. Marashdeh and N. Abdullah, 2012. Financial development and economic growth in the UAE: Empirical assessment using ARDL approach to Co-integration. Int. J. Econ. Finance, 4: 105-115. DOI: 10.5539/ijef.v4n5p105

Al-Saati, A.R., 2003. The permissible gharar (risk) in classical Islamic jurisprudence. J. King Abdul-Aziz Uni. Islamic Econ., 16: 3-19.

Azouzi, D. and A. Echchabi, 2013. Islamic banking and economic growth: The Kuwait experience. Middle East J. Manage., 1: 186-195. DOI: 10.1504/MEJM.2013.057262

Conley, J.D., 2012. Financial development and economic growth in Kentucky countries. $\mathrm{PhD}$ Thesis, Agricultural Economics, University of Kentucky.

Dickey, D.A. and W.A. Fuller, 1979. Distribution of the estimators for autoregressive time series with a unit root. J. Am. Statistical Association, 74: 427-431. DOI: 10.1080/01621459.1979.10482531

El-Galfy, A. and K.A. Khiyar, 2012. Islamic banking and economic growth: A review. J. Applied Bus. Res., 28: 943-956.

Furqani, H. and M. Ratna, 2009. Islamic banking and economic growth: Empirical evidence from Malaysia. J. Economic Cooperation Develop., 30 : 59-74.

Goaied, M. and S. Sassi, 2011. Financial development and economic growth in the MENA Region: What about Islamic banking development. Int. J. Bus. Manage. Sci., 4 : 1-23.

Granger, C., 1969. Investigating causal relations by econometric models and cross-spectral methods. Econometrica, 37 : 424-438.

Halicioglu, F., 2007. The financial development and economic growth nexus for Turkey. MPRA paper No. 3566, Department of Economics, Yeditepe University. 
Johansen. S. and K. Juselius, 1990. Maximum likelihood estimation and inference on cointegration-with applications to the demand for money. Oxford Bull. Econ. Statistics, 52: 169-210.

DOI: $10.1111 / \mathrm{j} .1468-0084.1990 . \mathrm{mp52002003.x}$

Khan, A., 2000. The finance and growth nexus. Bus. Rev., 2000: 3-14.

McKinnon, R.I., 1973. Money and Capital in Economic Development. 1st Edn., Brookings Institution Press, Washington, ISBN-10: 0815718497, pp: 184.

Miniaoui, H. and G. Gohou, 2011. Did the islamic banking perform better during the financial crisis? Evidence from the UAE. Proceedings of the International Conderence on Management, Economics and Social Sciences, (ICMESS'11), Bangkok, pp: 630-635.

Phillips, P.C.B and P. Perron, 1988. Testing for a unit root in time series regression. Biometrika, 75: 335-346. DOI: $10.1093 /$ biomet/75.2.335

Pradhan, R.P., 2009. The nexus between financial development and economic growth in India: Evidence from Multivariate VAR Model. Int. J. Res. Rev. Applied Sci., 1: 141-151.

Rivzi, M., 2012. Islamic Banking flourishing.
Shan, J. and Q. Jianhong, 2006. Does financial development 'lead' economic growth? The case of China. Ann. Econ. Finance, 1: 197-216.

Shaw, E.S., 1973. Financial Deepening in Economic Development. 1st Edn., Oxford University Press, New York, pp: 260.

Stievano, A.D.C., 2004. Finance-growth nexus in open economies with outliers. Banca Intesa-Res. Division, Department of Financial and Management Studies, SOAS, University of London.

Stolbov, M., 2013. The finance-growth nexus revisited: From origins to a modern theoretical landscape. Econ. Economics: Open-Access, Open-Assessment E-J., 7: 1-22.

Sunde, T., 2012. Financial sector development and economic growth nexus in South Africa. Int. J. Monetary Econ. Finance, 5: 64-75. DOI: 10.1504/IJMEF.2012.044467

Ujunwa, A., O. Ekumankama, H.A. Umar and M.I. Adamu, 2012. Finance and growth nexus in Nigeria: Do bank-based and market-based argument matter? Int. J. Bus. Manage., 7: 112-121.

DOI: $10.5539 / \mathrm{ijbm} . v 7 \mathrm{n} 23 \mathrm{p} 112$ 